\title{
Professional vision of future English language teachers: subject-specific noticing and knowledge-based reasoning
}

\section{Klára Uličná}

\begin{abstract}
The article focuses on future English language teachers' professional vision. Specifically, we explore what important subject-specific moments they notice in a lesson, i.e. noticing or selected attention; and how they reason about these moments, i.e. knowledge-based reasoning. We focus on important moments related to the subject of teaching English/English language teaching methodology at the end of their master studies. Students were asked to write an unstructured reflection based on an observation of videoed English language lesson. The reflections were analysed in comparison to expert analysis of the lesson. Students approximately commented two important moments (experts six) and most of their comment were of descriptive and evaluative nature. They did not show any deep ability to connect the seen to some underlying theory, nor to provide some theory-based alterations or predictions.
\end{abstract}

Keywords: Preservice English language teachers, English language teaching methodology, professional vision, teacher noticing, knowledge-based reasoning. 


\title{
Profesní vidění budoucích učitelů angličtiny: specifické pozorování a uvažování založené na vědění
}

\begin{abstract}
Abstrakt
Text je zaměřen na profesní vidění budoucích učitelů anglického jazyka. Zejména se zaměřujeme na to, jakých důležitých oborově specifické jevů si studenti ve výuce všímají, tzv. všímání si neboli výběrové zaměření pozornosti; a jak o nich přemýšlejí, tzv. uvažování založené na vědění. V ohnisku našeho zájmu jsou jevy spojené s didaktikou anglického jazyka na konci magisterského studia. Studenti měli za úkol napsat reflexi na základě pozorování videozáznamu hodiny anglického jazyka. Reflexe byly analyzovány a porovnány s expertními analýzami stejné hodiny. Studenti byli schopni identifikovat cca dva oborově specifické jevy (experti šest) a většina jejich komentářů byla popisné a hodnotící povahy. Studenti naopak neprojevili schopnost propojovat viděné s teorií či navrhovat na teorii založené alterace a predikce.
\end{abstract}

Klíčová slova: př́pravné vzdělávání učitelů, didaktika anglického jazyka, profesní vidění, všímání si, uvažování založené na vědění.

\section{Introduction}

It seems to be a natural phenomenon, that different people perceive same events differently, in other words, our ability to notice differs. The reasons are many, for instance awareness of context, background knowledge or previous experience. In a number of studies connected to this phenomenon, it is described by a concept of so called professional vision. Goodwin (1994, p. 606) described professional vision as "socially organized ways of seeing and understanding events". These ways of seeing and understanding events are often organized by a connection to a profession since members of professions share some common knowledge base as well as practical experience. In this text, our framework will be the context of the teaching profession, or more precisely the context of pre-service teacher education. It is a period during which a wide spectrum of professional knowledge and skills has to be developed together with the ability of (self)reflection. Teachers in the Czech Republic are commonly being prepared in the field of pedagogical and psychological disciplines, subject based disciplines and subject didactics. Besides theoretical preparation, there is a practical part of teacher education mainly in the form of teaching practice at schools. The interconnection of theoretical and practical part of teacher preparation may also be realized by observations of real teaching and its reflection. 
Observations are one of the key techniques supporting teachers' professional growth. It is a reflective technique which develops deeper understanding to the processes of teaching and learning. Furthermore, it may influence one's own teaching practice. Thus, observations promote the development of three dimensions of teachers' professionalism, i.e. (1) professional vision: noticing or seeing a situation influenced by an affiliation with a profession, (2) professional knowledge: knowledge by which members of a profession dispose of, and (3) professional action: a sum of accepted and established practices performed within a profession (for more detail see e.g. Janík et al., 2016, p. 12-13).

In this study, we shall focus on professional vision of future English language teachers as a specific subculture within the profession. We focus on one subject only since a number of studies emphasises that teaching is strongly influenced by the specific context of the subject matter being taught, for instance Grossman and Stodolsky (1995) talk about specific subject related subcultures with their own believes, norms and practices ${ }^{1}$. In the context of English language teaching, Borg (2006) pointed to a study by Hammadou and Bernhardt (1987) who discussed the specifics of foreign language teachers and claimed that becoming a foreign language teacher differs from becoming a teacher of different subjects. The key factor is the foreign language itself, because foreign language communicative competence is the aim, content, and also the means how to reach it.

Belonging to a specific subculture influences one's ability to notice subject-specific moments in teaching, i.e. one's selective attention. Here, we focus on future English language teachers at the end of their pre-service teacher education in other to uncover the nature of their ability to notice and reason about subject-specific phenomena.

We believe that the obtained data will support our understanding to what the students notice when observing English lessons and how they reason about it. Furthermore, the outcomes should bring valuable information about teacher education with specific attention being paid to subject didactics.

\section{Theoretical rationale: professional vision in teacher education}

Much has been written on the topic of professional vision. It has been deeply elaborated on from the theoretical as well as research perspective (e.g. Sherin, 2007; van Es \& Sherin, 2002, 2006, 2010; in the Czech context e.g. Minaříková, 2014; Minaříková et al., 2015; Janík et al., 2016; Stehlíková, 2010; Vondrová \& Žalská, 2015).

Most elaborated seems to be the context of mathematics, e.g. Borko, H., Jacobs, J., Eiteljorg, E., \& Pittman, M. E. (2008); Sherin, M. G., Jacobs, V. R., \& Philipp, R. A. (2011); Vondrová, N. \& Žalská, J. (2015). 
Professional vision is a concept which describes seeing phenomena in a situation from the perspective of expertise which differs from seeing the same by laymen (Goodwin, 1994). The nature of professional vision is thus closely connected to expertise, in our case to teacher expertise, therefore, we believe, it should be paid attention to as early as during the pre-service teacher education. Professional vision consists of two interrelated processes: (1) noticing, or selective attention - what phenomena the teacher pays attention to, and (2) knowledge-based reasoning - how the teacher reasons about the phenomena he or she notices (Sherin, 2007).

Research into the nature of professional vision enables us to uncover, what do the representatives of a particular profession, in our case student teachers, notice in teaching, and how they think about about the seen. Sherin and van Es (2009) for instance work with noticing different topics (subject matter, pedagogy, climate, classroom management) and actors (teacher, pupil, self, curriculum designer), and with reasoning about them - so called stance (description, evaluation, interpretation). However, studies which elaborate only on selective attention only, or on knowledge-based reasoning also exist.

Studies on noticing do not usually focus on subject related phenomena only. They are usually researched together with other phenomena (e.g. Sherin and van Es above). However, student teachers should be trained to distinguish between less and more important events in teaching. Star, Lynch and Perova $(2011$, p. 120) point out the fact that some classroom events are certainly more important than others, and it is crucial that student teachers are able to attend to and interpret these important events. However, questions whether they should firstly be trained to distinguish either the important classroom events, or a full range of general events remains. If important classroom events are taken into consideration, it should be the moments which play the key role in pupils' learning the subject, such as types of tasks etc. (Vondrová \& Žalská, 2015).

Studies on knowledge-based reasoning mainly vary in what stance they adopt on the processes of reasoning about the noticed phenomena. Sherin and van Es distinguish between three levels of stance (see above). Stockero (2008) differentiates five levels: describing, explaining, theorizing, confronting and restructuring. Based on some more categorial systems, Minaríková (2014) introduced a six level system to capture the knowledge-based reasoning: description, interpretation, explanation (equals the theorizing above), prediction, evaluation and suggesting alteration. Last but not least Janík et al. (2016) also introduced six levels of reasoning: description, interpretation, generalization, evaluation, alteration and selfreflection.

In this study, we attempt to capture the nature of professional vision through a research in both, noticing and knowledge-based reasoning. Our primary concern is student teachers' ability to notice and reason about subject-specific phenomena at the end of their master studies. In other words, we are mainly interested in the pedagogical content knowledge (Shulman, 1987) of teachers to be. 


\section{Research}

\subsection{Aim and research questions}

The aim of the study was to investigate the nature of professional vision of future English language teachers. Attention was thus paid to the area of students' selective attention, specifically their ability to notice domain-specific phenomena in observed lessons. Furthermore we looked into the area of reasoning about the identified phenomena. Our research was motivated by an attempt to answer the following research questions:

1. What important subject-specific moments do future English language teachers notice?

2. How do future English language teachers reason about the noticed phenomena?

\subsection{Research methodology}

\section{Research sample}

The participant were 47 student teachers at the end of their studies. 23 of them were future elementary school teachers (ISCED 1) with specialization in English; 24 of them were future lower and upper secondary school teachers of English (ISCED 2 and 3).

\section{Data collection: choice of lesson and task}

For data collection, a video of a school lesson of 45 minute length was used. It was a lesson of English in the $8^{\text {th }}$ grade from a lower secondary school. The video was taken in the school year 2014/2015. This video was chosen on the bases of its content variability, since it includes a number of general, but more importantly subject-specific phenomena ${ }^{2}$ (Blomberg, Stürmer, \& Seidel, 2011). The video captures an authentic lesson which is easy to be understood by an observer, contains clear beginning and end, and thus does not need any more contextual information. The lesson focuses on teaching new grammar - relative pronouns.

Students were asked to observe the lesson and write an unstructured reflection. The length of the reflection was not prescribed. They were to write everything they considered important. They were told that there were no correct or wrong answers and that the reflection will not be evaluated in any way. They could watch the video as many times as they felt needed. The data were collected during the last semester of a study year 2015/2016. Students wrote the reflections at home and submitted them by e-mail. 47 written observations were received.

2 Which was confirmed by the expert analysis of the lesson by a team of six teacher educators across various disciplines. 


\section{Data analysis}

The data analysis included both, (1) noticing subject-specific phenomena, and (2) knowledge-based reasoning.

1) Noticing subject-specific phenomena in the videoed lesson of English was analysed in two steps:

Firstly, an expert analysis of the lesson was realized in order to identify the important subject-specific moments that occur in the lesson. An inductive content analysis was employed. The author of this study, an English language teaching methodologist, and five methodologists of other subjects involved in teacher education observed the video independently and identified the moments under investigation. Consequently, the identified moments were discussed and a set of six English language teaching specific phenomena (see Table 1) were agreed on. Inviting experts from different disciplines to observe the lesson and identify the important moments ensured that the identified phenomena were well noticeable.

Table 1

English language teaching specific phenomena

\begin{tabular}{|l|l|}
\hline Subject-specific expert phenomenon & Student teachers comment on \\
\hline E13: warm-up activity - countability & $\begin{array}{l}\text { The way countable and uncountable nouns are revised, including questions How } \\
\text { much/How many. The way this grammatical issue is practised. }\end{array}$ \\
\hline E2: teacher language 1 - code switching & $\begin{array}{l}\text { The langauge the teacher uses with specific attention paid to using English and Czech } \\
\text { (the mother tongue). The way the teacher using mainly English influences the pupils. }\end{array}$ \\
\hline E3: teacher language 2-accuracy & $\begin{array}{l}\text { The language the teacher uses with specific attention paid to using un/accurate } \\
\text { langauge, especially concerning selected langauge subskills: pronunciation and } \\
\text { grammar. }\end{array}$ \\
\hline E4: teacher talking time & $\begin{array}{l}\text { The amount of time the teacher talks, i.e. teacher talking time (TTT). On one hand } \\
\text { the TTT seems to be quite high, on the other hand it provides langauge model, i.e. } \\
\text { language to be acquired by pupils. }\end{array}$ \\
\hline E6: inductive teaching of relative pronouns & $\begin{array}{l}\text { The way pupils are led to work with a text to come up with the rules of using relative } \\
\text { pronouns. }\end{array}$ \\
\hline E7: transfer to real language use & $\begin{array}{l}\text { The way the teacher emphasises the role of relative pronouns in real English langauge } \\
\text { use, e.g. by presenting situations in which relative pronouns might help when using } \\
\text { English in authentic communication. }\end{array}$ \\
\hline
\end{tabular}

Secondly, reflections written by students based on observing the video were analysed. A deductive content analysis using the above categorial system (Table 1) was conduct-

3 The codes E1 to E7 stand for: E - English specific expert phenomena; numbers only distinguish between the phenomena, there is no hierarchical purpose. There are six phenomena, however, there is no E5 code due to the process of identifying the phenomena in the expert group. 
ed in order to find out which important subject-specific moments identified by experts are also being identified by students at the end of their pre-service teacher education.

2) To investigate the knowledge-based reasoning about the subject-specific phenomena, we used a categorial system in which we modified the existing levels of reflection (see chapter 2 above). Our categorial system consists of six levels of reflection (see Table 2).

Table 2

Knowledge-based reasoning - six levels of reflection

\begin{tabular}{|l|l|}
\hline Knowledge-based reasoning & Student teachers comment on \\
\hline 1: Description & $\begin{array}{l}\text { Description of a situation which was seen in the lesson. Objectively descriptive, not interpreta- } \\
\text { tive. }\end{array}$ \\
\hline 2: Explanation & $\begin{array}{l}\text { Lay or naïve explanation of what was seen in the lesson based on one's own experience as } \\
\text { a pupil or as a teacher }\end{array}$ \\
\hline 3: Theorisation & Interpretation and generalisation of what was seen using an underlying theory. \\
\hline 4: Evaluation & Evaluation of what was seen. \\
\hline 5: Alteration & Suggesting an alternative to what was seen. \\
\hline 6: Prediction & Suggesting predictions of what impact can the seen have in the future. \\
\hline
\end{tabular}

In order to answer our research questions, we first analysed the written observations to identify the parts in which students noticed and commented on the important subjectspecific moments E1 to E7 (Table 1). Consequently, each identified unit was further assigned one or more knowledge-based reasoning codes (for example see Table 3 ).

Table 3

\section{Example of coding}

\begin{tabular}{|l|l|c|c|c|c|}
\hline $\begin{array}{l}\text { Code } \\
\text { (Table 1) }\end{array}$ & Coded unit & \multicolumn{4}{|c|}{ Code (Table 2) } \\
\cline { 2 - 6 } & $\begin{array}{l}\text { I would like to start with the first activity which was focused on countable } \\
\text { and uncountable nouns. Each student got a card with a picture and his/ } \\
\text { her task was to show the card to the others and ask "how much" or "how } \\
\text { many". Other students answered according to the picture. It was a revision } \\
\text { of the grammar the students did last lesson. To this activity I have one } \\
\text { suggestion, it might be better if each student went to the blackboard in } \\
\text { order for everyone to see the picture. Otherwise I think this activity was } \\
\text { chosen appropriately and the students did a good job. }\end{array}$ & yes & yes & yes & no \\
\hline
\end{tabular}


All the units were identified and coded independently by two researchers. In a case of a discrepancy, the difference was negotiated until a $100 \%$ agreement was reached.

\section{Findings and discussion}

109 units (which equals $100 \%$ ) were identified in the 47 analysed reflections. Figure 1 shows the frequency of occurrence of the subject-specific expert phenomena transferred to percentage proportions (i.e. the first research question).

Figure 1

Subject-specific expert phenomena occurrence

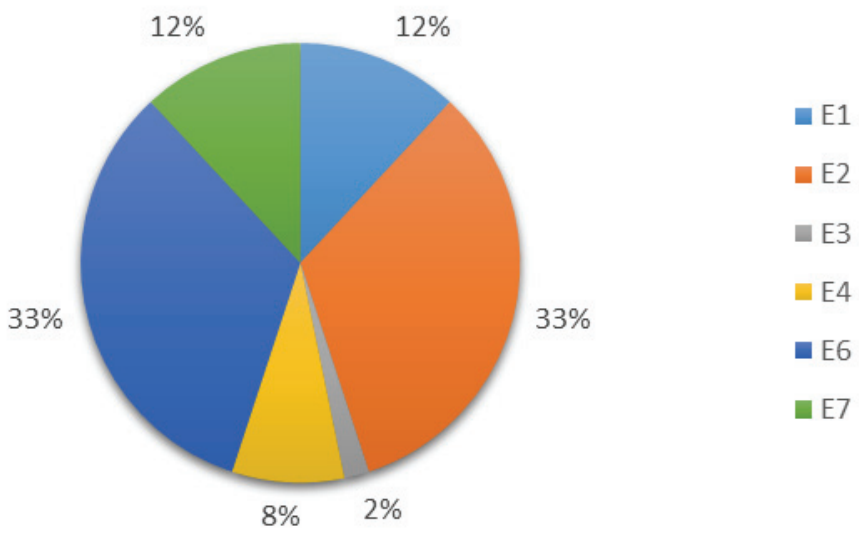

It is apparent from the figure above that students notice E2: teacher language 1 - code switching and E6: inductive teaching of relative pronouns the most (both $33 \%$ ). After that, with the same frequency of occurrence (12\%) they paid attention to E1: warm-up activity - countability and E7: transfer to real language use. Even less (8\%) the students noticed E4: teacher talking time. Finally, an insignificant occurrence (2 \% representing two students only) of E3: teacher language 2 - accuracy was identified.

Concerning the second process of professional vision under investigation, i.e. knowledge-based reasoning, we identified 263 codes (which equals $100 \%$ ) with the attributes of various ways of reasoning about the noticed units (109 units). One unit, i.e. one subject-specific expert phenomena noticed by the students was commented on by approximately 2.41 knowledge-based reasoning codes. However, what interests us is the frequency of occurrence of the knowledge-based reasoning codes which is 
presented in Figure 2 transferred to percentage proportions (i.e. the second research question).

\section{Figure 2}

Knowledge-based reasoning codes occurrence

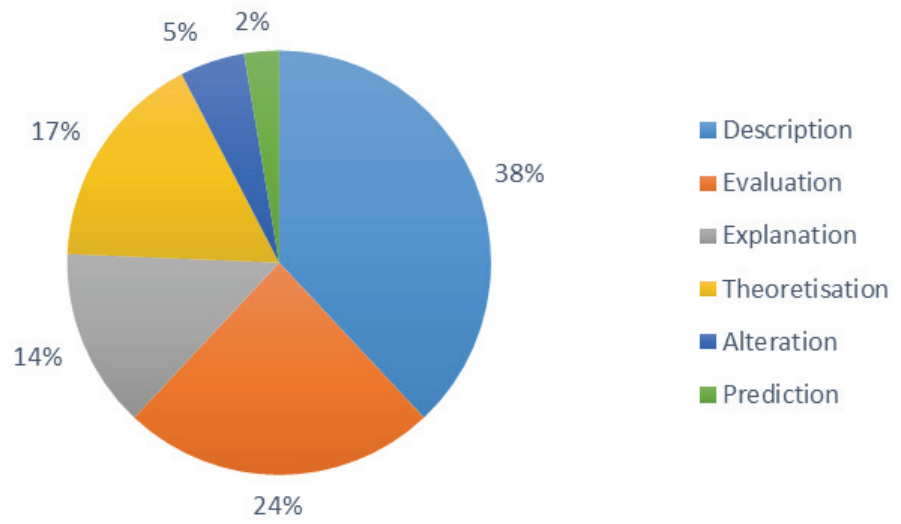

It is obvious that mostly the students described and evaluated the seen. On the contrary there were very few predictions made. It seems the students do not tend to connect the seen to the consequences it might mean. It is in accord with Kersting et al. (2010) who claim that suggestions for instructional improvement might be a sign of expertise of practising teachers.

Furthermore, we believe, that an insight into the combinations of codes, i.e. what the students notice and how they reason about it, is a good starting point for a discussion (see Table 4). Unfortunately, due to the lack of space, the data are mainly presented in a table with interesting boxes (i.e. the highest occurrence) highlighted by grey.

Table 4

Combination of noticing and knowledge-based reasoning

\begin{tabular}{|c|c|c|c|c|c|c|c|c|}
\hline Phenomena & Phen. occurrence & Description & Evaluation & Explanation & Theoretisation & Alteration & Prediction & Total \\
\hline E1 & $12 \%$ & $13 \%$ & $13 \%$ & $19 \%$ & $0 \%$ & $31 \%$ & $0 \%$ & $12 \%$ \\
\hline E2 & $33 \%$ & $35 \%$ & $40 \%$ & $53 \%$ & $14 \%$ & $38 \%$ & $29 \%$ & $35 \%$ \\
\hline E3 & $2 \%$ & $1 \%$ & $3 \%$ & $3 \%$ & $2 \%$ & $0 \%$ & $0 \%$ & $2 \%$ \\
\hline E4 & $8 \%$ & $9 \%$ & $8 \%$ & $11 \%$ & $7 \%$ & $23 \%$ & $0 \%$ & $9 \%$ \\
\hline E6 & $33 \%$ & $29 \%$ & $24 \%$ & $6 \%$ & $59 \%$ & $8 \%$ & $57 \%$ & $29 \%$ \\
\hline E7 & $12 \%$ & $13 \%$ & $13 \%$ & $8 \%$ & $18 \%$ & $0 \%$ & $14 \%$ & $13 \%$ \\
\hline
\end{tabular}


Most knowledge-based reasoning codes were connected to one of the mostly occurred expert phenomenon E2: teacher language 1 - code switching. It is quite logical, since changing the English and Czech language is quite easy to be noticed, the students mostly describe it, positively evaluate the high use of English, which they explain, however, unfortunately, they only rarely connect it to some underlying theory of language acquisition. Some students suggest, that even the limited use of Czech langauge could be omitted and they suggest alterations, however, it is a very rare case since the $38 \%$ is only represented by 5 students (see Figure 2).

Phenomenon E6: inductive teaching of relative pronouns was also paid much attention, It was commented on mainly through theorising and predicting. It is quite interesting that inductive grammar teaching made the students thing of the theory of teaching grammar as well as predicting that this approach to grammar teaching will help the students to remember the learnt better.

\section{Conclusions}

We hope this text serves as a good insight into the nature of professional vision of future English langauge teachers at the end of their master studies. Specific attention was paid to phenomena related to English langauge teaching methodology and how students reason about them. The results show how much and in what way do English language teaching methodology and teaching practice effect the students' ability to pay attention to important moments in teaching and how deeply they think about them.

To find out we used a videoed lesson in which six expert phenomena were present and well observable. Altogether the 47 students noticed 109 phenomena, which means approximately 2,3 phenomena per student. The results thus show, that the students' ability to notice important moments in a lesson cannot be claimed to be high. Our results are in accord with the study by Vondrová and Žalská (2015) who worked with future mathematics teachers at the end of their study and found out that the median for the number of expert phenomena per student was 2 (the expert rate was 6). These results may guide us towards some changes in teacher education, especially the interconnection of theory and practice, as well as to some further research. Firstly we may compare the outcomes for the two study programmes, English teachers for ISCED 1 and for ISCED 2 and 3. Furthermore, we may also compare these result with results from the beginning of the students' university study to capture their development. Secondly, we would like to investigate the nature of knowledge-based reasoning comments. Last but not least a different lesson might be used for the data collection which might bring slightly different expert phenomena into play, however, likely the same reasoning processes. 


\section{Acknowledgment}

The study has been financially supported by project PRVOUK P15 The school and teaching profession in the context of growing educational demands.

\section{References}

Blomberg, G., Stürmer, K., \& Seidel, T. (2011). How pre-service teachers observe teaching on video: Effects of viewers' teaching subjects and the subject of the video. Teaching and Teacher Education, 27(7), 1131-1140.

Borg, S. (2006). The discintive characteristics of foreign language teachers. Language Teaching Research, 10(1), 3-31.

Borko, H., Jacobs, J., Eiteljorg, E., \& Pittman, M. E. (2008). Video as a tool for fostering productive discussions in mathematics professional development. Teaching and Teacher Education, 24(2), 417-436.

Goodwin, C. (1994). Professional vision. American Anthropologist, 96(3), 606-633.

Grossman, P.L., \& Stodolsky, S.S. (1995). Content as context: The role of school subject in secondary school teaching. Education Researcher, 24(8), 5-11.

Janík, T., Minaříková, E., Píšová, M., Uličná, K., \& Janík, M. (2016). Profesní vidění učitelů a jeho rozvíjení prostřednictvím videoklubů. Brno: Masarykova univerzita.

Kersting, N. B., Givvin, K. B., Sotelo, F. L., \& Stigler, J. W. (2010). Teachers' analyses of classroom video predict student learning of mathematics: Further explorations of a novel measure of teacher knowledge. Journal of Teacher Education, 61(1/2), 172-181.

Minaříková, E. (2014). Profesní vidění studentů učitelství anglického jazyka: jak vidí studenti výukové situace zachycené na videu? Pedagogická orientace, 24(5), 753-777.

Minaříková, E., Janík, T., Uličná, K., \& Janík, M. (2015). Videokluby jako forma profesního vzdělávání. Př́spěvek prezentovaný na Výroční konference České pedagogické společnosti.

Sherin, M. G. (2007). The development of teachers' professional vision in video clubs. In R. Goldman, R. Pea, B. Barron, \& S. Derry (Eds.), Video research in the learning sciences (pp. 383-395). Hillsdale, NJ: Lawrence Erlbaum.

Sherin, M. G., Jacobs, V. R., \& Philipp, R. A. (2011). Situating the study of teacher noticing. In M. G. Sherin, V. R. Jacobs, \& R. A. Philipp (Eds.), Mathmatics teacher noticing. Seeing through teachers' eyes (pp. 3-13). New York: Routledge.

Sherin, M., \& van Es, E. (2009). Effects of video club participation on teachers' professional vision. Journal of Teacher Education, 60(1), 20-37.

Shulman, L. B. (1987). Knowledge and teaching: foundations of the new reform. Harvard Educational Review, 57(1), 1-22.

Star, J. R., Lynch, K., \& Perova, N. (2011). Using video to improve preservice mathematics teachers' abilities to attend to classroom features: A replication study. In M. G. Sherin, V. R. Jacobs, \& R. A. Philipp (Eds.), Mathematics Teacher Noticing: Seeing Through Teachers'Eyes (pp. 117-133). New York and London, Taylor \& Francis.

Stehlíková, N. (2010). Interpretace některých didakticko-matematických jevů u studentů učitelství a u učitelů matematiky. Pedagogika, 60(3-4), 303-313.

Stockero, S. L. (2008). Using a video-based curriculum to develop a reflective stance in prospective mathematics teachers. Journal of Mathematics Teacher Education, 11(5), 373-394. 
van Es, E. A., \& Sherin, M. G. (2002). Learning to notice: Scaffolding New Teachers' Interpretations of Classroom Interactions. Journal of Technology and Teacher Education, 10(4), 571-596.

van Es, E. A., \& Sherin, M. G. (2006). How Different Video Club Designs Support Teachers in „Learning to Notice". Journal of Computing in Teacher Education, 22(4), 125-135.

van Es, E. A., \& Sherin, M. G. (2010). The infuelnce of videoclubs in teachers' thinking and practice. Journal of Mathematics Teacher Education, 113(2), 55-176.

Vondrová, N., \& Žalská, J. (2015). Ability to Notice Mathematics Specific Phenomena: What Exactly Do Student Teachers Attend to? Orbis scholae, 9(2), 77-101.

\section{Contact:}

Mgr. Klára Uličná, Ph.D.

Department of English Language and Literature

Faculty of Education, Charles University

Celetná 13, 11000 Prague 1, Czech Republic

Phone: +420773086043

E-mail: klara.ulicna@pedf.cuni.cz

PhDr. Klára Uličná, Ph.D. received her Ph.D. in a study programme Philology from the Department of English Language and ELT Methodology, Faculty of Arts, Charles University in Prague. Specializing in ELT Methodology, she teaches mainly Factors of the Teaching and Learning Processes, Methods and Approaches to English Language Teaching and Teaching Skills and Subskills, and Videoclubs. Furthermore she participates in Teaching practice organization and reflection, usage of professional portfolios and action plan/research guidance. Her research interests include pedeutology (e.g. novice teachers, teacher expertise), teacher education, future teacher reflection, and analysis and conceptualization and development of intercultural communicative competence. 